瀶床 乳糜胸腹水を呈した非ホジキンリンパ腫の 1 例

\author{
大阪大学医学部第四内科 \\ 楽木宏実 荻原俊男 三上 洋 片平克俊 能原雄一 \\ 東大阪市立東病院 岩坪晴彦 波多 丈 \\ 大阪大学医学部放射線科池田 恢 \\ 大阪大学医学部第一外科 板倉丈夫
}

\begin{abstract}
概要 乳糜胸水, 乳糜腹水は共にまれな病態であり，特に悪性リンパ腫を原因とする報告は外 国例と異なり，本例では数例にすぎない，最近われわれは，乳糜胸水と乳糜腹水とを合併して 発症した覀性リンパ腫の 1 症例を経験した。発症時表在リンパ節の腫脹は著明でなかつたが, CT検査，リンパ節生検により非ホジキンリンパ凬と診断した。高カロリー輸液により全身状態 の改善をはかると共に，種々の化学療法を施行したが無効であり，放射線療法が著効を奏した。 本邦での全リンパ董は増加傾向にあり，乳糜胸腹水は積極的に悪性リンバ腫を疑うへき所見で あると認識する必要がある。

(日内会誌 $75 ： 1109 \sim 1114 ， 1986$ 〕
\end{abstract}

\section{緒 言}

17世紀に最初の報告を認めるとされる1乳糜胸 水・乳糜腹水は共になれな病態であり, 特に本邦 ではいずれも報告例は100例に満たない，さらに， 乳糜胸水と乳糜腹水との合併例は極めて亲れであ り，本邦では 2 例を認めるにすぎない233)。また， 原因疾患としては，外国例では悪性リンパ腫が多 数認められるのに対し，本邦では乳糜胸水に 3 例(4)5，乳糜腹水に 1 例6)の報告をみるのみである。 最近われわれは，乳糜胸水と乳糜腹水とを合併し て発症した悪性リンパ腫の 1 症例を経験した。本 例は，発症時表在リンパ節の腫脹は著明でなく， 乳糜胸・腹水のみを初発臨床所見として発症した 極めてまれな症例である。

\section{症例}

患者：36才, 男性.

主訴：腹部膨満.

既往歴：特記すべきものなし，手術歴，外傷 歴共になし。
家族歷： 特記すべきものなし.

現病歴：昭和59年夏より，腹部の膨隆を自覚 しはじめたが放置. 同年 9 月中旬より悪心，腹部 膨満が増強したため某院を受診.腹部CT検査によ り後腹膜に腫瘤陰影を指摘された．利尿薬の投与 を受けるも改善せず，腹部膨満がさらに増強した ため他に転院，腹水，右胸水の貯留著明で，その 性状はいずれも乳糜様。抗酸菌染色, 結核菌培養 はともに陰性であつたが，診断的治療の意味でイ ソニアジド，リファンピシン，ストレプトマイシ ンによる抗結核薬療法を施行するる無効であつ た。昭和 59 年11月乳糜胸腹水の原因精査, 加療を 目的に当科入院.

入院時現症：身長 $171 \mathrm{~cm}$, 体重 $62 \mathrm{~kg}$, 血王 $108 / 80 \mathrm{mmHg}$, 脈拍 $80 /$ 分, 整, 体温 $36.2^{\circ} \mathrm{C}$. 眼䀫 結膜に䂓血なし。眼球結膜に黄染なし。表在リン ハ節； 鎖骨上窝, 腋窝, 単径部に数個触知. W ずれも0.5 1.0cm. 無痛性, 軟で, 可動性あり. 右胸郭；打聴診により胸水貯留を疑ら。心音は

\title{
[昭和60年 6 月27日受稿]
}

A case with non-Hodgkin lymphoma manifesting chylothorax and chylous ascites

Hiromi Rakugi, Toshio Ogihara, Hiroshi Mikami, Katsutoshi Katahira and Yuichi Kumahara

Department of Medicine and Geriatrics, Osaka University Medical School, Osaka

Haruhiko IWATSUBo and Takeshi Hata, Medical Department, Higashi-Osaka City Hospital, Osaka

Hiroshi IKEDA, Department of Radiology, Osaka University Medical School, Osaka

Takeo Itakura, The First Department of Surgery, Osaka University Medical School, Osaka 
純. 腹部に腹水貯留. 腹囲 $91 \mathrm{~cm}$ (㑪高). 肝脾腫は 腹水のため不明，下肢は前怪骨部浮腫なし．神経 学的検査に異常なし（図 1 ）.

入院時検査成績：1）血液および生化学検査 （表 1)；電解質，肝機能などに異常を認めず. 血浆レンン活性(PRA), 血浆アルドステロン濃度 $(\mathrm{PAC})$ 高値で, 二次性アルドステロン症の像を呈 した. 各種腫瘍マーカーのらち, エラスターゼ 1 , CA 125が異常高值を示した. 2) 免疫学的検査(表 2)； ッベルクリン反応陰性. 免度グロブリン全 般の低下があり, 細胞性, 液性両免疫能の低下が

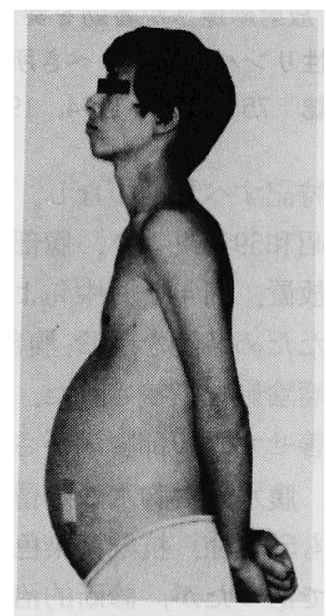

図 1. 本報告例の入院時上半身側面像

表 1 . 入院時検査成績

\begin{tabular}{|c|c|c|c|c|c|}
\hline \multicolumn{4}{|l|}{ 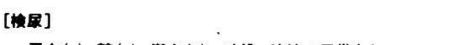 } & \multicolumn{2}{|l|}{ [ } \\
\hline 自白け。 & 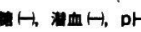 & 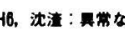 & & $a \mathrm{FP}$ & $<5 \mathrm{ng} / \mathrm{m} \ell$ \\
\hline [末来粗血] & & & & CEA & $<1 \mathrm{ng} / \mathrm{m} \ell$ \\
\hline mit & $13 \mathrm{~m} / \mathrm{m}$ & 白血理 & $8400 / \mathrm{cmm}$ & CA19-9 & $19 \mathrm{u} / \mathrm{m} 2$ \\
\hline 赤血理 & $531 \times 10 \% / \mathrm{cm}$ & St & $5 \%$ & IラX3-せi & $1350 \mathrm{ng} / \mathrm{de}$ \\
\hline $\mathrm{Hb}$ & $14.6 \mathrm{~g} / \mathrm{d} \ell$ & $S_{\theta \theta}$ & $80 \%$ & CA12 5 & $>500 \mathrm{u} / \mathrm{m} \ell$ \\
\hline $\mathrm{Ht}$ & $44 \%$ & Eo & $1 \%$ & [内分湖] & \\
\hline 血小板 & $45 \times 10^{4} / 0 \mathrm{~mm}$ & $\mathrm{Ba}$ & $1 \%$ & PRA & $51.5 \mathrm{ng} / \mathrm{m} / \mathrm{hr}$ \\
\hline フィシリォ & 原虫 & Ly & $10 \%$ & PAC & $67.1 \mathrm{ng} / \mathrm{dl}$ \\
\hline [血洨化 $*$ ] & & Mo & $3 \%$ & T. & $0.4 \mu \mathrm{g} / \mathrm{dl}$ \\
\hline 血洒 $\mathrm{Ne}$ & $138 \mathrm{mEq} / \mathrm{L}$ & 政血白 & $5.1 \mathrm{~g} / \mathrm{de}$ & $T$, & $95 \mathrm{ne} / \mathrm{de}$ \\
\hline K & $5.5 \mathrm{mEq} / \mathrm{L}$ & $A / G$ & 1.4 & RT,U & $30.2 \%$ \\
\hline $\mathrm{Cl}$ & $96 \mathrm{mEq} / \mathrm{L}$ & アルオミン & $58.8 \%$ & TSH & $10.8 \mu \mathrm{U} / \mathrm{ml}$ \\
\hline $\mathrm{Ca}$ & $4.4 \mathrm{mEq} / \mathrm{L}$ & タロブリンa & $6.2 \%$ & コルチ・うール & Ib $\quad 14.7 \mu \mathrm{g} / \mathrm{dl}$ \\
\hline $\mathrm{Pi}$ & $4.4 \mathrm{mg} / \mathrm{d} \ell$ & & $17.7 \%$ & ACTH & $39 \mathrm{pg} / \mathrm{ml}$ \\
\hline クレアチニン & $1.3 \mathrm{mg} / \mathrm{dl}$ & $\beta$ & $11.6 \%$ & 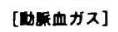 & \\
\hline BUN & $15 \mathrm{mg} / \mathrm{de}$ & $\gamma$ & $5.7 \%$ & $\mathrm{pH}$ & 7.408 \\
\hline GOT & $15 \mathrm{U} / \mathrm{L}$ & TTT & 10 & $\mathrm{pO}_{2}$ & $66.1 \mathrm{mmHg}$ \\
\hline GPT & $12 \mathrm{U} / \mathrm{L}$ & カヒヒリルビン & $0.6 \mathrm{mg} / \mathrm{dl}$ & $\mathrm{pCO}_{2}$ & $36.5 \mathrm{mmHg}$ \\
\hline AL-P & $188 \mathrm{U} / \mathrm{L}$ & $F_{\theta}$ & $63 \mu / d e$ & $\mathrm{SO}_{2}$ & $91.0 \%$ \\
\hline LDH & $218 \mathrm{U} / \mathrm{L}$ & UIBC & $200 \mu \mathrm{g} / \mathrm{de}$ & $\mathrm{BE}$ & $-1.2 \mathrm{mEq} / \mathrm{L}$ \\
\hline 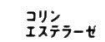 & $2076 \mathrm{U} / \mathrm{L}$ & $\mathrm{Cu}$ & $137 \mu \mathrm{g} / \mathrm{de}$ & $\mathrm{HCO}_{5}^{-}$ & $22.7 \mathrm{mE} / \mathrm{L}$ \\
\hline
\end{tabular}

認められた. リンパ球幼若化試験, OKTシリーズ でも T細胞（特にヘルパー, インデューサー), B 細胞機能低下が認められた。3）X線検査； i) 胸部 X線像(図 2 ). 右胸水貯留著明。左胸水も認 めた。心扗大なし。 ii）胸部CT像. 縦隔・肺門部 のリンパ節腫脹なし、 iii) 腹部CT (困 3 ). 腹膜,

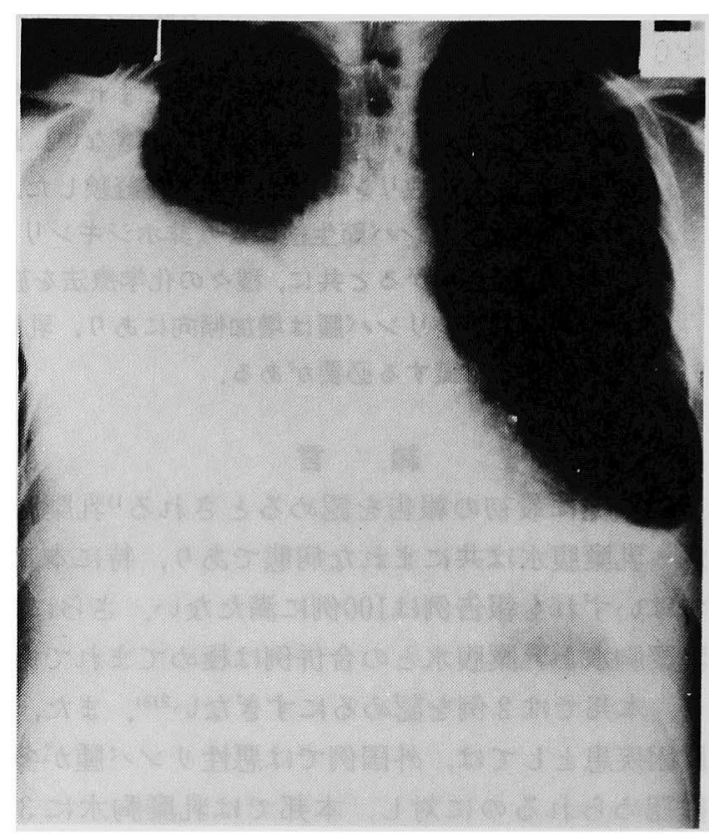

図 2. 入院時胸部 X線像写真

表 2 、免疫学的検査

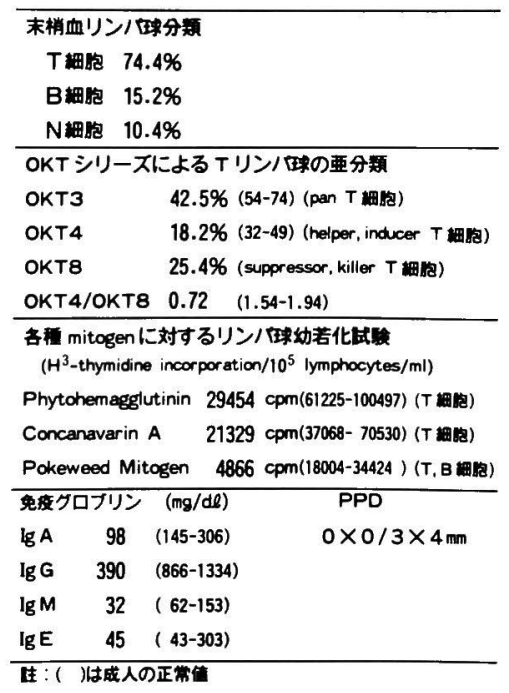


傍大動脈，上腸間膜動脈周囲のリンパ節腫脹およ び, 腸間膜にBulky mass (直径 $10 \mathrm{~cm}$ 以上のリン パ節腫脹)を認める.iv）リンパ管造影では, リン パ漏出部位を描出できず。ガリウムシンチグラ フィーでは転移巣を認めなかつた，4）胸水・腹水 穿刺； 穿刺液はいずれも乳糜様であり, ェーテ ルを加えて振盪すると透明化した。 また，検鏡に より脂肪滴を認めた(表 3 )。穿刺液の細胞診はい ずれもクラスIIであり，経過を通じて悪性細胞の 出現をみなかつた，5）リンパ節生検(Virchowリ ンパ節)。 i）組織診断。悪性リンパ腫； diffuse small cleaved cell type (図 4 ). ii) 免疫学的診

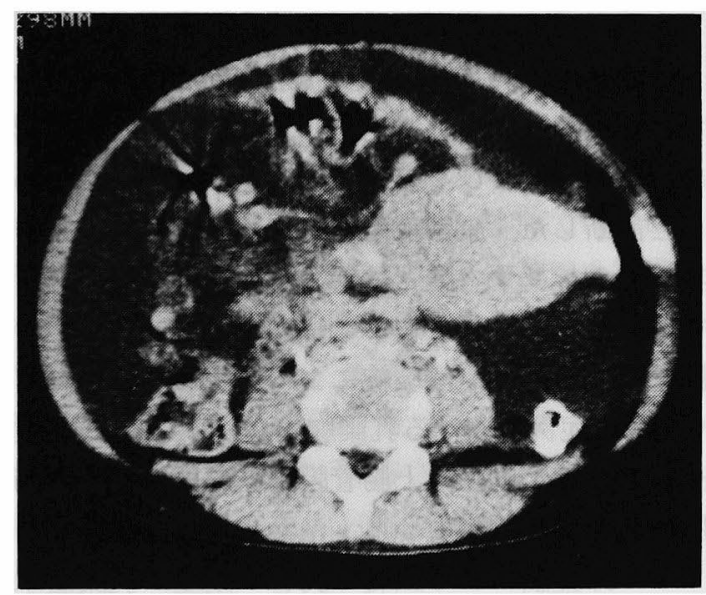

図 3. 入院時腹部CT写真

表 3 . 入院時胸・腹水性状および生化学的検査成績

\begin{tabular}{|c|c|c|c|}
\hline & 水 & 量水 & 血 \\
\hline & 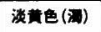 & 淡糞色 (灀) & \\
\hline & 用 棈 & 趾棈 & \\
\hline 比 & 1.020 & 1.025 & \\
\hline$\therefore$ 鈞 & $1300 / \mathrm{m}^{3}$ & $2000 / \mathrm{mm}^{3}$ & \\
\hline 杼中理 & $5.5 \%$ & $4.5 \%$ & \\
\hline リンバ玦 & $94.0 \%$ & $95.0 \%$ & \\
\hline 粗轨 & $1.0 \%$ & $0.5 \%$ & \\
\hline 谏 & クラスII & クラスII & \\
\hline 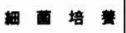 & $(-)$ & $(-)$ & \\
\hline 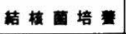 & $(-)$ & $(-)$ & \\
\hline 战タンバ & $3.8 \mathrm{~g} / \mathrm{de}$ & $4.3 \mathrm{~g} / \mathrm{de}$ & $5.1 \mathrm{~g} / \mathrm{d} \ell$ \\
\hline$A / G$ & 2.5 & 1.3 & 1.4 \\
\hline はコレステロール & $71 \mathrm{mg} / \mathrm{de}$ & $64 \mathrm{mg} / \mathrm{de}$ & $166 \mathrm{mg} / \mathrm{de}$ \\
\hline 中性频 & $138 \mathrm{mg} / \mathrm{d} \ell$ & $436 \mathrm{mg} / \mathrm{de}$ & $156 \mathrm{mg} / \mathrm{dl}$ \\
\hline 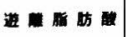 & $625 \mu \mathrm{Eq} / 2$ & $767 \mu \mathrm{Eq} / \ell$ & $585 \mu \mathrm{Eq} / \ell$ \\
\hline カイロミク & $151 \mathrm{mg} / \mathrm{de}$ & $731 \mathrm{mg} / \mathrm{de}$ & $59 \mathrm{mg} / \mathrm{dl}$ \\
\hline : & $121 \mathrm{mg} / \mathrm{de}$ & $128 \mathrm{mg} / \mathrm{dl}$ & $82 \mathrm{mg} / \mathrm{dl}$ \\
\hline
\end{tabular}

断； 表面免度グロブリンはIgG. light chainは $\lambda$. E-口ゼット形成試験陰性. 各種 B細胞表面マー カー陽性 (表 4 ).

以上より，両側乳糜胸水扣よび乳糜腹水を呈し た悪性リンパ腫（非ホジキンリンパ腫）と診断し た。組織分類は, diffuse small cleaved cell type (intermediate grade), 機能分類はB 細胞型, 病 期分類はStage IVであつた。

臨床経過(図 5 )：乳糜流量を減少させる目的 で低脂肪食としたが，腹囲増大が続くため，高カ ロリー輸液に変更した。 4 週後には胸腹水の乳糜 様外観は消失した．悪性リンパ厙の診断の下に, $\mathrm{CHOP}$ 療法(サイクロホスファミド900mg, アドリ アマイシン $40 \mathrm{mg}$, ビンクリスチン $2 \mathrm{mg}$, プレド= ゾロン $100 \mathrm{mg} \times 5)$, PACO療法 (ペプレオマイシン $20 \mathrm{mg} \times 3$, アドリアマイシン $20 \mathrm{mg} \times 2$, サイクロホ

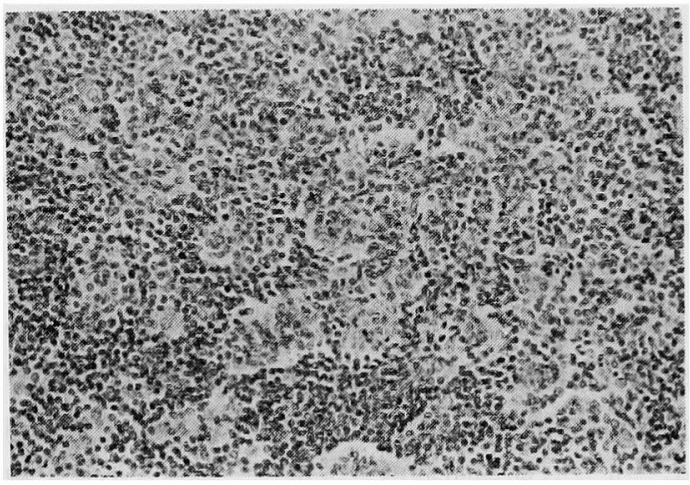

図 4.Virchow リンパ節生検組織像（HE染色, $\times 400$ ).

表 4. 生検リンパ節の免疫学的検查結果

\begin{tabular}{|c|c|}
\hline 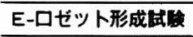 & $12.5 \%$ \\
\hline \multicolumn{2}{|c|}{ Surface immunoglobulin (s-lg) } \\
\hline Polyvalent & $85.0 \%$ \\
\hline $\operatorname{Ig} G$ & $81.0 \%$ \\
\hline $\lg M$ & $1.5 \%$ \\
\hline $\lg D$ & $1.0 \%$ \\
\hline \multicolumn{2}{|l|}{ Light chain } \\
\hline$\kappa$ & $1.0 \%$ \\
\hline$\lambda$ & $73.0 \%$ \\
\hline \multicolumn{2}{|l|}{ 日湅胞表面マーカー } \\
\hline $\mathbf{B}_{1}$ & $173 / 200$ \\
\hline $\mathrm{DKB}_{2}$ & $166 / 200$ \\
\hline FMC -7 & $150 / 200$ \\
\hline la DR & $185 / 200$ \\
\hline
\end{tabular}




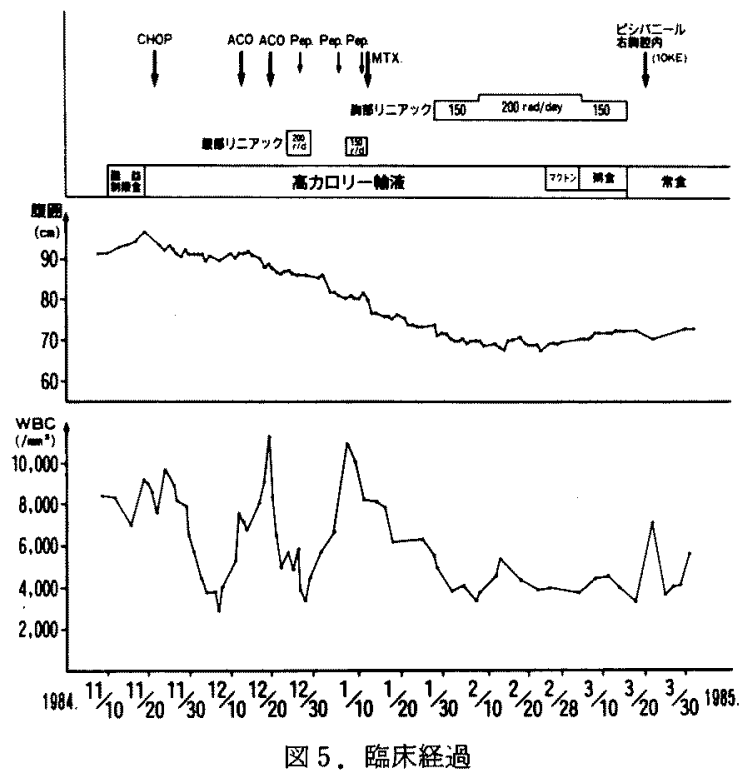

スファミド $800 \mathrm{mg} \times 2$, ビンクリスチン $2 \mathrm{mg} \times 2$ ), およびMTX療法（メソトレキセート50mg）を施 行したが，腹囲の若干の減少を認めたものの，胸 部 X線, 腹部CT検查上明らかな効果を認めなかつ たため，放射線療法に变更した。

放射線療法は, 10MV-X線を用い, 腹腔内主要り

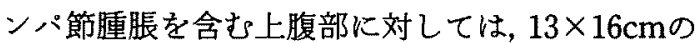
照射野で前後対向 2 門により行なつた. $1750 \mathrm{cGy} /$ 10回/18日の照射により，腹部CT検查にて腹水消 失，リンパ節著明縮小を認めた，胸部への放射線 照射は，乳糜胸水の原因となるべき畽瘤像を胸部 CT検查によつても胸郭内に認めなかつたため, 縦 隔から右全肺野に対して 3 力所に区分して総計 $3050 \mathrm{cGy} / 17$ 回ないし2550cGy/15回の照射がなさ れた。照射中，発熱，咳嗽などの症状，扣よび胸 部X線像上の肺陰影自体の変化は認められず，呼 吸機能は右胸水貯留の程度に応じて变化した。し かし，胸水貯留は改善されず，ピシバニール10KE により胸膜瘑着を実施した。その直後発熱を認め たが軽快し， 3 力月後胸水再貯留を認めていない。 また，全経過中胸水，腹水，骨䯣，末梢血に悪性 細胞を認めていない。
表 5、乳糜胸・腹水およびそれらの合併例の報告

\begin{tabular}{|c|c|c|c|c|c|c|}
\hline 告䅈 & 年 & 间龂 & 外但性 & 非外国性 & 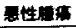 & 特基社 \\
\hline \multicolumn{7}{|l|}{ 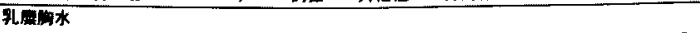 } \\
\hline Nix JT et al & 1957 & 123 & 68 & 36 & $20(?)$ & 19 \\
\hline Roy $\mathrm{PH}$ et al & 1967 & 52 & 5 & 35 & $34(23)$ & 12 \\
\hline MacFarland JR & 1972 & 15 & 4 & 7 & $7(4)$ & 4 \\
\hline Selle JG et al & 1973 & 15 & 8 & 4 & $2(1)$ & 3 \\
\hline 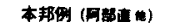 & 1979 & 79 & 38 & 18 & $6(3)$ & 23 \\
\hline \multicolumn{7}{|l|}{ 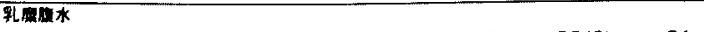 } \\
\hline Nix JT et al & 1957 & 146 & 15 & 100 & $39(?)$ & 31 \\
\hline Kelley \& Butt & 1960 & 69 & 0 & 69 & $62(33)$ & 0 \\
\hline Vasko \& Tapper & 1967 & 81 & 9 & 52 & $24(0)$ & 20 \\
\hline Press OW et al & 1982 & 28 & 2 & 25 & $21(12)$ & 1 \\
\hline $\begin{array}{l}\text { 帮用 } \\
\text { (Tsuchiye } M \text { et al) }\end{array}$ & 1973 & 85 & 2 & 43 & $15(1)$ & 40 \\
\hline \multicolumn{7}{|l|}{ 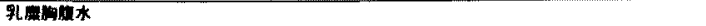 } \\
\hline Nix JT et al & 1957 & 33 & 4 & 29 & $19(?)$ & 0 \\
\hline 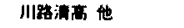 & 1961 & 1 & & 1 & & \\
\hline 枸田保形 他 & 1970 & 1 & & & & 1 \\
\hline Press OW et al & 1982 & 5 & 0 & 5 & $?$ & 0 \\
\hline
\end{tabular}

\section{考案}

本症例では，入院時の胸腹水穿刺液にエーテル を加之て振盪すると透明化し，検鏡で脂肪滴を認 めたこと、およびその生化学的性状より乳糜であ ると診断した。原因疾患は，リンパ節生検に上り 非ホジキンリンパ腫と診断した。乳糜が胸腔ある いは腹腔内に眝留することは，まれな病態であり， 胸管の閉塞あるいは破綻によつて生じるとされて いる. 本症例に打ける乳糜胸腹水の病態は, CT検 查により傍大動脈，上腸管膜動脈周囲のリンパ節 腫脹および腸間膜のBulky massを認め,これらの リンパ節腫脹による広範な胸管の閉塞が乳糜腹水 の原因と考光られた，乳麻胸水については，CT検 查上縦隔内に胸管閉塞の原因となるべきッンパ節 腫脹を認めず，悪性リンパ腫の浸潤などによる胸 管の破綻が推定された。しかし，このような広範 な腹腔内リンパ節異常が認められたにも拘らず， 表在リンパ節の腫脹は少なく，悪性リンパ腫とし て特異な経過であつたと考えられる。

一般に，胸管は解剖学的に，第 2 腰椎前面の乳 糜槽に始委り，大動脈の右後方に沿つて上行，大 動脈裂孔を通つて右胸腔に入り第 $5 \sim 6$ 胸椎の高 さで左胸腔に移り，左静脈角へ合流している。従 つて，乳糜の貯留空は胸管の傷害部位と関保し， 一般には乳糜槽から大動脈裂孔までの傷害は乳糜 腹水を，第 $5 \sim 6$ 胸椎より下位の傷害は右乳糜胸 水を,それより上位の傷害は左乳糜胸水を呈する。 
しかし, 本症例のように同時に両側乳糜胸水, 乳 糜腹水をきたしている報告例2337)14) むあり，胸管 の広範囲な傷害，横隔膜の異常等により出現し5 る. 乳糜の胸管内流量は23 $234 \mathrm{ml} / \mathrm{h}$, 平均 $1 \mathrm{ml} /$ minとされ，1 日量では約 $1.5 l$ にもおよが9). 従つ て，胸管が傷害された場合の胸・腹水貯留は著し く速く, 本症例でも $2 l$ の腹水穿刺後 2 日で腹用が 復元し，再穿刺を余儀なくされた。

乳糜胸・腹水の原因については，1）外傷性，2） 非外傷性，3）特発性の三つに分類できる，表 5 に 主な報告例を一覧表とした。本邦における集計で は, 乳糜胸水78例の阿部ら ()の報告, 乳糜腹水85例 のTsuchiya $ら^{6)}$ の報告がある，いずれも悪性腫場 に伴うものは，2例，および15例と少数である. これに対し，外国例では悪性腫瘍に伴う比率が高 い.

予後は，乳糜胸・腹水とも原疾患に左右される ため悪性腫瘍の占める割合の低い本邦では死亡率 む低い、阿部ら゙の報告によれば，本邦での乳糜胸 水78例について, 治瘺69例, 死亡 4 例, 不明 5 例 である。これに対し，外国例では乳糜胸水例で $10 \sim 30 \%^{12) 15) 16}$, 乳糜腹水例（成人例）て 56〜87\% ${ }^{1144}$ の死亡率が報告されている。ただし， 乳糜腹水の小児例では原疾患に悪性腫瘍が少ない

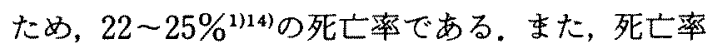
と治療方法については報告により成績が様々で, 原疾患に対する治療選択が第一と思われる。

本症例では, 入院後, 絶食による乳糜流量の減 少を目的に高カロリ一輸液を実施した。これによ り胸腹水の乳糜性の消失を認めた。一方, 腹囲で みる限り若干の改善傾向はあつたが, 化学療法の 効果も考えられて判然としなかつた。しかし，全 身状態の維持に対しては非常に有効であつた，最 終的に腹水の消失には放射線治療が著効を示し， 乳糜胸腹水の治療上, 原因療法の重要性を再認識 させる症例であつた。

次に，本症例の原因疾患であつた悪性リンパ腫 の立場から胸水貯留について考察する. Bruneau ${ }^{17}$ は，悪性リンパ腫の自験例64例の5ち 21 例（33\%）に胸水を認め，かつその15例 (71\%)
にはレントゲン線像上縦隔のリンパ節腫脹を認め なかつたが，放射線治療は胸水改善に有効であつ たとしている。蓑た，(Craver ${ }^{18)} は ，$ 悪性リンパ腫 で胸水を認めた場合，穿刺を繰り返す前に放射線 治療を第一に試みるべきであると述べている，本 症例の場合，これに相違して放射線治療により胸 水改善を認めなかつたが，一般的には胸部のリン パ節腫脹の有無に拘らず，悪性リンパ腫に伴う胸 水には放射線治療が有効であるといえる.

本邦に括ける乳糜胸腹水の原因として悪性りン パ盾が比較的少ないのは，悪性リンパ腫そのもの の頻度が訂正死亡率にして米国 8.77 人/男 10 万人, 日本 4.24 人/男 10 万人 $\left(1975\right.$ 年 $\left.{ }^{19)}\right)$ と，本邦におい て低いことが一因と考えられる。しかしながら， Bruneau $^{17)}, \mathrm{Craver}^{18)}$ の報告にみるように, 胸部に $\mathrm{X}$ 線像上悪性リンパ腫を示寸徵候がなくても悪性 リンパ腫を疑つて精查する必要がある，特に，本 症例の場合，表在リンパ節腫脹が著明ではないの に乳糜胸腹水を呈するという特異な経過をとつて 扣り，発症期には悪性リンパ腫に関係のありそう な身体所見は乳糜胸腹水だけであつたとすいえ る. また，本邦の悪性リンパ腫の頻度 ${ }^{20)} は ，$ 最近20 年間（1957年～1978年）で死亡総数にして1169か ら3266に増加しており，この意味です乳糜胸腹水 例では積極的に悪性リンパ腫を疑らべき必要性が 本邦でも增してきていると考学られる。

\section{結語}

極めてまれな乳糜胸水と乳糜腹水とを合併して 発症した悪性リンパ腫の 1 例を経験した。本症例 は，発症時表在リンパ節腫脹などは著明でなく， CT検査,リンパ節生検により診断され，化学療法 は無効であつたものの, 放射線療法が著効を示し 寛解を得た。乳糜胸腹水之悪性リンパ腫との関係 について，若干の文献的考察を加えて報告した。

謝辞病理組織診断に御協力載いた大阪大学医学部病理 病態学講座 青笹克之先生に深謝致します。

\section{文献}

1) Vasko JS and Tapper RI: The surgical significance of chylous ascites. Arch Surg 95: $355,1967$.

2）川路清高, 他：乳糜胸腹水を伴つた肺線維症の 1 
例. 日本病理学会誌 $50: 181,1961$.

3）梅田俊彦，他：乳糜胸・腹水を呈した 1 例。日内 会誌 $59: 549,1970$.

4) 阿部 直, 他：特発性乳糜胸。呼吸之循環 27 : $605,1979$.

5）福嶋和文，他：画側乳糜胸で初発し，末期にLeukemic Transformationを呈した悪性りンバ腫の 1 例. 日胸疾会誌 $20: 451,1982$.

6) Tsuchiya $M$, et al: Chylous ascites formation and a review of 84 cases. Angiology $24: 576$, 1973.

7) Nix JT, et al: Chylothorax and chylous ascites, a study of 302 selected cases. Amer J Gastroenterology 28: 40, 1957.

8) Stranahan A, et al : Operative thoracic ductography. J Thorac Surg 31 : 183, 1956.

9) Dumont $\mathrm{AE}$ and Mulholland JH : Alterations in thoracic duct lymph flow in hepatic cirrhosis. Ann Surg 156: 668, 1962.

10) Roy PH, et al: The problem of chylothorax. Mayo Clin Proc 42 : 457, 1967.

11) MacFarland JR, et al: Chylothorax. Amer Rev Respir Dis 105: 287, 1972.

12) Selle JG, et al : Chylothorax : Indications for surgery. Ann Surg $177: 245,1973$.
13) Kelley ML, Jr and Butt HR: Chylous ascites: An analysis of its etiology. Gastroenterology 39: 161, 1960.

14) Press OW, et al: Evaluation and management of chylous ascites. Ann Intern Med 96: 358, 1982.

15) Goorwitch J, et al: Traumatic chylothorax and thoracic duct ligation. J Thorac Surg 29: $467,1955$.

16) Gefel A, et al: Chylothorax, report of two cases and review of the literature. Israel $\mathrm{J}$ Med Sci 8: 522, 1972.

17) Bruneau $R$, et al : The management of pleural effusions and chylothorax in lymphoma. Radiology 85: 1085, 1965.

18) Craver LF, et al: Treatment of Hodgkin's disease. (In) Treatment of cancer and allied disease, Vol 9, ed by GT Pack and IM Ariel, New York, Hoeber Medical Division, Harper \& Row, Inc, 2nd ed, 168, 1964.

19）田島和雄：特集悪性リンバ腫, 疫学・治療学 7: $495,1981$.

20）厚生大臣官房統計情報部：人口動態䌅計．昭和 32 - 56年, 厚生效計協会. 